\title{
INVESTIGATION OF THE EFFECT OF 8 WEEKS CORE TRAINING PROGRAM ON FREE SHOOTING AND VERTICAL JUMP PERFORMANCE IN BASKETBALL PLAYERS AGED 16-18
}

\author{
Vesile Şahineri, \\ Feyzullah Koca ${ }^{2}$ \\ ${ }^{1}$ Erciyes University, \\ Health Sciences Institute, \\ Turkey \\ ${ }^{2}$ Assoc. Prof., \\ Erciyes University, \\ Faculty of Sport Sciences, \\ Turkey
}

\begin{abstract}
:
The aim of this study is to investigate the effects of the core training program applied for 8 weeks to basketball players aged 16-18 on free throw and vertical jump performance. 22 male basketball players (11 experimental group, 11 control group) aged 16-18 participated in the study voluntarily. While core training was applied to the basketball players in the experimental group, 2 days a week for 8 weeks, together with the basketball training, the basketball players in the control group only continued their routine basketball training. Free throw and vertical jump performance tests were applied to the subjects before applying the 8-week core training program (pre-test) and after the 8-week core training (post-test). Statistically significant difference was found between pretest and posttest in terms of experimental group free throw test values $(p<0.05)$ Statistically significant difference was found between the pretest and posttest values of the control group in terms of free throw test values $(p<0.05)$. When the experimental group and control group free throw pretest and posttest were compared, no statistical significance was found ( $p>0.05)$. A statistically significant difference was found between the pretest and posttest in terms of vertical jump test values of the experimental group and the control group $(p<0.05)$. However, the development in the experimental group was higher than in the control group. There was no statistically significant difference between the free throw test difference mean values of the experimental group and the control group $(p>0.05)$. A statistically significant difference was found between the vertical jump test difference mean values of the experimental group and the control group $(p<0.05)$. As a result, it can be said that 8 -week core training has positive effects on the development of
\end{abstract}

${ }^{i}$ Correspondence: email vsl.shnr.18@gmail.com 
vertical jump performance on basketball players, but no effect on free throw performance.

Keywords: basketball, core training, free throw, vertical jump

\section{Introduction}

Basketball, which has shown a significant development since the day it was played by James Naismith in 1891, is among the sports branches that are watched with interest in Turkey and in the world (Larousse, 1988). Basketball, which is a sports game that is increasing in popularity day by day and watched with interest, is one of the games played as a team (Sevim, 1991). Basketball is a sport branch where it is necessary to have maximum motor skills (Erol, 1992). Also, anaerobic activities including explosive strength such as jump is more dominant in basketball according to activity profile in game although it is seen a sport branch that anaerobic capacity is not very effective in terms of game duration (Ar1 et al., 2017). In order to achieve advanced performance in the basketball branch, current scientific methods should be used. In order to reach the elite level in every sport branch, theoretical knowledge, psychological preparation, technical and tactical training as well as conditioning training are among the basic elements. Being scientific in sports is necessary for success at the international level (Sevim, 1991). In the basketball branch, where many changes in body position are required, the transmission of force occurs through the core region in jumping shots or tourniquet shots. Also, it is indicated that muscle mass is important in sport branches requiring strength and power (Ari and Deliceoglu, 2020). Balance and postural control are also provided through the muscles in the core region (Willardson, 2014).

The core region, in which the center of gravity of the human body is located, is an area consisting of a total of 29 different muscles covering the abdomen, waist, hips and pelvis (Samson, 2005; Bostanci et al., 2020). In a sense, the force dynamics in the body are formed by the muscles in the core region. The amount of force produced by the muscles in the core region may not be as high as some muscles in other parts of the body, but the core muscles have an important function in carrying the force correctly and protect other muscles in the body with this feature (Yilmaz et al., 2020). When the muscles in the core area are strong, it prevents other muscles in the body from being damaged, so an athlete's well-developed core muscles make it easier for this athlete to adapt to extreme loads. Developing the athlete's body strength in a balanced way will enable her to learn and practice a movement technically easily (Mcgill, 2010; Mayda et al., 2016). The forces produced in movements such as tourniquets and smash specific to the basketball branch pass through the core region to stimulate the movements of multiple muscles in order to maintain balance and postural control (Gambetta, 2007).

Shooting is the most important determinant in determining the score return and result of a match, gaining the upper hand and winning the game (Malone et al., 2002). Basketball is a branch where the continuity of the conditional and technical characteristics 
is necessary. The most used condition and technical features in basketball are strength and shooting (Kelley, 2003). Free throws are very important in competition, as they provide numbers that are favorable for the team's score, that can be won without the opponent, and these numbers are considered to be won as a team. It has an important role in gaining superiority in a competition and winning the competition (Malone et al., 2002).

Jumps that occur in the vertical plane are called vertical jumps. The main purpose of the vertical jump movement is to rise vertically from the bottom (from the ground) up from the directional angle, while the result is to gain height relative to the ground (Aktuğ, 2013). Since jumping at a high level and quickly is the most important key to a successful performance, players and coaches are looking for new methods to improve leg strength and vertical jumping ability (Günay et al.,1994).

The action of the jump, in which complex movements are required, depends on the explosive strength, the technique of the jump, the strength of the leg muscles and the flexibility of all the muscles involved in the action. It is important for athletes to develop their jumping strength and to perform at a high level in this sport (Aktuğ, 2013).

The popularization of core training and the fact that it is a type of training that concerns all branches encouraged us to do this study. In this study, it was investigated whether it has an effect on free throw and vertical jump performance by applying a core training program to basketball players aged 16-18 for 8 weeks.

\section{Materials and Methods}

22 athletes between the ages of 16-18, who are in a men's basketball team in Kayseri province, voluntarily participated in the research. The subjects' height and length measurements were made with the help of a tape measure fixed vertically on a flat surface. Measurement results were recorded in centimeters $(\mathrm{cm})$. Body weight measurements of the subjects were measured in kilograms with a Tanita HD-358 brand electronic scale with $0.01 \mathrm{~kg}$ sensitivity. The subjects consisted of 2 groups as the experimental group $(\mathrm{n}=11)$ and the control group (control, $\mathrm{n}=11)$.

Training Program of the Groups: After the free throw and vertical jump preliminary tests were applied to the subjects, core training was applied to the experimental group 2 days a week in addition to basketball training for 8 weeks, while only routine basketball training was applied to the control group.

\subsection{Training Program}

Training Duration: 8 Weeks

Training Intensity: 2 days a week

One Training Time: 30-60 minutes

Load-Rest : $1: 1$ 
Table 1: 1st and 2nd Week Core Training Program

\begin{tabular}{|l|c|c|c|}
\hline Core Exercise Moves & Sets & $\begin{array}{c}\text { Repeat-Time } \\
\text { (sec) }\end{array}$ & $\begin{array}{c}\text { Rest } \\
\text { (sec) }\end{array}$ \\
\hline Sumo Squad & 3 & 45 & 45 \\
\hline Glute Raise & 3 & 45 & 45 \\
\hline Cat and Camel & 3 & 45 & 45 \\
\hline Quadruped Opposite Leg and Arm Raise & 3 & 45 & 45 \\
\hline Superman & 3 & 45 & 45 \\
\hline Dead Beg & 3 & 45 & 45 \\
\hline Toe Touch & 3 & 45 & 45 \\
\hline Russian Twist & 3 & 45 & 45 \\
\hline Leg Raise & 3 & 45 & 45 \\
\hline Front Plank & 3 & 45 & 45 \\
\hline
\end{tabular}

Table 2: 3rd and 4th Week Core Training Program

\begin{tabular}{|l|c|c|c|}
\hline Core Exercise Moves & Sets & $\begin{array}{c}\text { Repeat-Time } \\
\text { (sec) }\end{array}$ & $\begin{array}{c}\text { Rest } \\
\text { (sec) }\end{array}$ \\
\hline Sumo Squad & 4 & 30 & 30 \\
\hline Glute Raise & 4 & 30 & 30 \\
\hline Cat and Camel & 4 & 30 & 30 \\
\hline Quadruped Opposite Leg and Arm Raise & 4 & 30 & 30 \\
\hline Superman & 4 & 30 & 30 \\
\hline Dead Beg & 4 & 30 & 30 \\
\hline Toe Touch & 4 & 30 & 30 \\
\hline Russian Twist & 4 & 30 & 30 \\
\hline Leg Raise & 4 & 30 & 30 \\
\hline Front Plank & 4 & 30 & 30 \\
\hline
\end{tabular}

Table 3: 5th and 6th Week Core Training Program

\begin{tabular}{|l|c|c|c|}
\hline Core Exercise Moves & Sets & $\begin{array}{c}\text { Repeat-Time } \\
\text { (sec) }\end{array}$ & $\begin{array}{c}\text { Rest } \\
\text { (sec) }\end{array}$ \\
\hline Sumo Squad & 4 & 45 & 45 \\
\hline Glute Raise & 4 & 45 & 45 \\
\hline Cat and Camel & 4 & 45 & 45 \\
\hline Quadruped Opposite Leg and Arm Raise & 4 & 45 & 45 \\
\hline Superman & 4 & 45 & 45 \\
\hline Dead Beg & 4 & 45 & 45 \\
\hline Toe Touch & 4 & 45 & 45 \\
\hline Russian Twist & 4 & 45 & 45 \\
\hline Leg Raise & 4 & 45 & 45 \\
\hline Front Plank & 4 & 45 & 45 \\
\hline
\end{tabular}


Table 4: 7th and 8th Week Core Training Program

\begin{tabular}{|l|c|c|c|}
\hline Core Exercise Moves & Sets & $\begin{array}{c}\text { Repeat-Time } \\
\text { (sec) }\end{array}$ & $\begin{array}{c}\text { Rest } \\
\text { (sec) }\end{array}$ \\
\hline Sumo Squad & 5 & 30 & 30 \\
\hline Glute Raise & 5 & 30 & 30 \\
\hline Cat and Camel & 5 & 30 & 30 \\
\hline Quadruped Opposite Leg and Arm Raise & 5 & 30 & 30 \\
\hline Superman & 5 & 30 & 30 \\
\hline Dead Beg & 5 & 30 & 30 \\
\hline Toe Touch & 5 & 30 & 30 \\
\hline Russian Twist & 5 & 30 & 30 \\
\hline Leg Raise & 5 & 30 & 30 \\
\hline Front Plank & 5 & 30 & 30 \\
\hline
\end{tabular}

\subsection{Free Throw Measurement}

The free throw test recommended by the Turkish Basketball Federation and used in many researches around the world was applied (Şen, 1997). All participants made 10 shots to the basket from behind the free throw line. Participants repeated the test three times. Successful balls (passing through the hoop) after every 10 shots were noted, and evaluations were made after all shots were averaged. All participants were allowed to take a sighting shot before administering the test.

\subsection{Vertical Jump Measurement}

Vertical jump measurements of the subjects were made on the wall before and after the 8 -week core training program. The values obtained were recorded by asking the subjects to take a side-lying position near the wall and to extend their hands to the highest distance they could reach on the wall. The subjects were asked to jump as high as they could reach after their knees were ready at 90 degrees without making any springing movements, and the highest point they could reach was recorded (Özmen et al., 2017). Each test was repeated three times at 30-second intervals, and the best result was recorded.

\subsection{Experimental Design}

At the beginning of the study, the free throw and vertical jump test (pre-test) was applied to the experimental group and the control group. While the 8-week core training program was applied to the experimental group in addition to routine basketball training, the control group only participated in routine basketball training during this 8-week period. After 8 weeks of core training, free throw and vertical jump tests (post-test) were reapplied to the experimental group and the control group, and the resulting data were interpreted statistically, and a significant result was reached on whether the core training had a positive effect on the free throw and vertical jump performance. 


\subsection{Statistical Analysis}

Statistical analysis of the research data was made with Excel (Analyses Tool Pack) and SPSS 26 version package programs. In the first stage, descriptive statistical analysis of the data was carried out. Since the number of participants was less than 50, the Shapiro-Wilk test was used to control the normal distribution criteria. Since the variables showed normal distribution, the comparison of the experimental and control groups in the pretest and post-test measurements was carried out by applying the Independent Samples T-test, while the Paired Samples T-test was used in the pre-test and post-test evaluations of the data in the intra-group comparisons. The statistical values of the data are presented as mean, standard deviation, $\mathrm{t}$-score and $\mathrm{p}$-value. The significance level was accepted as 0.05 in all statistical analyses.

\section{Results}

Table 5: Descriptive Statistics of The Groups

\begin{tabular}{|l|l|c|c|}
\hline \multirow{2}{*}{ Variables } & \multirow{2}{*}{ Test } & $\begin{array}{c}\text { Experimental group } \\
(\mathbf{n = 1 1})\end{array}$ & $\begin{array}{c}\text { Control Group } \\
(\mathbf{n = 1 1 )}\end{array}$ \\
\cline { 3 - 4 } & & $\overline{\mathbf{x}} \pm \mathbf{S D}$ & $\mathbf{\mathbf { x }} \pm$ SD \\
\hline \multirow{2}{*}{ Age (years) } & Pre-Test & $16.64 \pm 0.80$ & $16.45 \pm 0.52$ \\
\cline { 2 - 4 } & Post-test & $16.64 \pm 0.80$ & $16.45 \pm 0.52$ \\
\hline \multirow{2}{*}{ Height $(\mathrm{cm})$} & Pre-Test & $183.73 \pm 9.07$ & $187.45 \pm 8.43$ \\
\cline { 2 - 4 } & Post-test & $184.36 \pm 9.16$ & $188.55 \pm 8.60$ \\
\hline \multirow{2}{*}{ Weight $(\mathrm{kg})$} & Pre-Test & $77.47 \pm 11.6$ & $77.19 \pm 9.33$ \\
\cline { 2 - 4 } & Post-test & $76.73 \pm 11.4$ & $78.37 \pm 8.69$ \\
\hline
\end{tabular}

(BMI: Body mass index, n: Number of Subjects)

Table 5 Shows the descriptive statistics of the experimental and control groups.

Table 6: Comparison of Free Throw Pre-Test-Post-Test

Values of Experimental and Control Groups

\begin{tabular}{|l|l|c|c|c|c|}
\hline \multirow{3}{*}{ Variables } & \multirow{2}{*}{ Test } & $\begin{array}{c}\text { Experimental group } \\
(\mathbf{n = 1 1 )}\end{array}$ & $\begin{array}{c}\text { Control Group } \\
(\mathbf{n}=\mathbf{1 1})\end{array}$ & \multicolumn{2}{|c|}{} \\
\cline { 3 - 6 } & & $\overline{\mathbf{x}} \pm$ SD & $\overline{\mathbf{x}} \pm$ SD & $\mathbf{t}$ & $\mathbf{\rho}$ \\
\hline \multirow{5}{*}{ Free Throw } & Pre-Test & $5.81 \pm 0.968$ & $5.66 \pm 1.182$ & 0.331 & 0.744 \\
\cline { 2 - 6 } & Post-Test & $6.81 \pm 0.750$ & $6.93 \pm 0.829$ & -0.361 & 0.722 \\
\cline { 2 - 4 } & $\mathrm{t}$ & -2.703 & -3.155 & & \\
\cline { 2 - 5 } & $\mathrm{Q}$ & 0.022 & 0.010 & \\
\hline
\end{tabular}

When the free throw performances of the experimental group and control group in Table 6. were examined, a statistically significant difference was found between the experimental group's free throw pretest and posttest $(\mathrm{p}<0.05)$. Statistically significant difference was found between the control group free throw pretest and posttest $(p<0.05)$. When the free throw pre-test and post-test averages of the experimental group and the 
control group were compared, there was no statistically significant difference between them $(\mathrm{p}>0.05)$.

Table 7: Comparison of Experiment Group and Control Group Vertical Jump Pre-Test-Post-Test Values

\begin{tabular}{|l|l|c|c|c|c|}
\hline \multirow{2}{*}{ Variables } & \multirow{2}{*}{ Test } & $\begin{array}{c}\text { Experimental group } \\
(\mathbf{n = 1 1})\end{array}$ & $\begin{array}{c}\text { Control Group } \\
(\mathbf{n}=\mathbf{1 1})\end{array}$ & \multicolumn{2}{|c|}{} \\
\cline { 3 - 6 } & & $\overline{\mathbf{x}} \pm$ SD & $\overline{\mathbf{x}} \pm$ SD & $\underline{\mathbf{t}}$ & $\boldsymbol{\rho}$ \\
\hline \multirow{3}{*}{$\begin{array}{l}\text { Vertical Jump } \\
(\mathrm{cm})\end{array}$} & Pre-Test & $46.64 \pm 6.607$ & $44.36 \pm 4.501$ & 0.943 & 0.357 \\
\cline { 2 - 6 } & Post-Test & $52.00 \pm 6.340$ & $46.82 \pm 5.193$ & 2.097 & 0.049 \\
\cline { 2 - 4 } & $\mathrm{t}$ & -26.386 & -3.849 & & \\
\cline { 2 - 6 } & $\mathrm{Q}$ & 0.000 & 0.003 & & \\
\hline
\end{tabular}

When the vertical jump performances of the experimental group and control group in Table 7. examined, a statistically significant difference was found between the experimental group vertical jump pretest and posttest $(\mathrm{p}<0.05)$. A statistically significant difference was found between the vertical jump pretest and posttest of the control group $(p<0.05)$. There was no significant difference between the experimental group and the control group pretests ( $\mathrm{p}>0.05)$. However, when the vertical jump performance posttests of the two groups were compared, a statistically significant difference was found between them $(\mathrm{p}<0.05)$.

Table 8: Comparison of Experiment Group and Control Group Free Throw and Vertical Jump Pre-Test-Post-Test Differences

\begin{tabular}{|l|l|c|c|c|c|}
\hline \multirow{2}{*}{ Variables } & \multirow{2}{*}{ Test } & $\begin{array}{c}\text { Experimental group } \\
(\mathbf{n = 1 1 )}\end{array}$ & $\begin{array}{c}\text { Control Group } \\
(\mathbf{n = 1 1})\end{array}$ & \multicolumn{2}{|c|}{} \\
\cline { 3 - 6 } & & $\overline{\mathbf{x}} \pm \mathbf{S D}$ & $\overline{\mathbf{x}} \pm \mathbf{S D}$ & $\underline{\mathbf{t}}$ & $\boldsymbol{\rho}$ \\
\hline \multirow{2}{*}{ Difference } & Free Throw & $1,00 \pm 1,22$ & $1,15 \pm 1,51$ & $-0,261$ & 0,796 \\
\cline { 2 - 6 } & Vertical Jump & $5,36 \pm 0,674$ & $2,45 \pm 2,11$ & 4,347 & 0,000 \\
\hline
\end{tabular}

When the difference mean values of the free throw and vertical jump performances of the experimental group and the control group in Table 8 examined, there was no statistically significant difference between the mean of free throw test difference between the experimental group and the control group $(p>0.05)$. However, when the vertical jump test mean differences were compared between the experimental group and the control group, a significant difference was found $(p<0.05)$.

\section{Discussion and Conclusion}

As a result of the core training applied to the basketball players for 8 weeks, a significant difference was found between the experimental group free throw pretest and posttest. A significant difference was found between the control group free throw pretest and posttest. Gür and Ersöz (2017) examined the effects of core training on dynamic and static balance properties and core strength by applying core training to tennis players aged 8- 
14, and found that core training had a positive improvement in body stability and body strength on tennis players as sportive performance. The fact that core training strengthens and increases the stability of the muscles in the core region allows the athletes to transfer their strength to power efficiently. For this reason, core training allows the technical movements to be performed by the athletes using a lower amount of energy, and the athletes are less exposed to the effects of fatigue caused by long-term work. (Mcgill, 2010). Gürpınar et al. (2009) stated in a study on basketball players that there was a greater improvement in the shooting performance of young basketball players, whom they practiced strength training in addition to shooting training, compared to basketball players who only practiced shooting. This is an indication that strength training is effective on shooting performance. However, in our study, there was no significant difference between the experimental group and control group free throw pretest and posttest. This shows that the effects of basketball training are the same in both groups, but the effects of core training applied to the experimental group do not make a significant difference.

When the vertical jump pre-test and post-test values of the experimental group were examined, it was seen that there was a significant difference between them. A significant difference was found between the control group's vertical jump performance pretest and posttest. While there was no significant difference between the vertical jump pretests of the experimental group and the control group, a significant difference was found between the posttests of the two groups. The fact that Boyaci and Afyon (2017) determined that the core training program applied for 3 months in children aged 12-14 playing football had significant effects on the vertical jump performance of the athletes also supports our study.

Sharrock et al. (2011) stated that core training has positive effects on sportive performance. Since regular core training provides development in the muscles in the core region (Steven et al., 2011), the developing core muscles ensure that the muscles in the upper extremity and lower extremity work in harmony (Akuthota and Nadler, 2004). Since this harmony will contribute to the proper realization of technical skills, it supports our study.

When the results of the measurements in our study were evaluated, as a result of the core training program applied to the experimental group for 8 weeks; An improvement was detected in the vertical jump performances of the subjects. However, no significant difference was observed in free throw performances. More improvement was observed in the vertical jump test of the experimental group compared to the control group. It can be thought that the lack of a statistically significant difference in the results of the free throw test may be due to the fact that the psychological state of the individual, as well as the physical capacity, affects the free throw performance more than the vertical jump skill. In addition, although there was a significant improvement between the pretest and post-tests of the control group, there was no significant difference between the two groups. 
In conclusion, it is thought that core training is not effective for the development of free throw skill. However, we think that core training in the basketball branch may be effective on the vertical jumping skills of the athletes and that it may be beneficial to include core training in basketball training programs.

\section{Acknowledgement}

This article was created from a master's thesis.

\section{Conflict of Interest Statement}

There are no potential conflicts of interest on this article.

\section{About the Authors}

Vesile Şahiner has a Master of Science degree in the sport science field.

Assoc. Dr. Feyzullah Koca is Associate Professor, Erciyes University, Turkey.

\section{References}

Aktuğ, Z. B. (2013). Futbolcularda İzokinetik Hamstring Ve Quadriceps Kas Kuvvet Oranı İle Dikey Sıçrama Ve Sürat Performans İlişkisi. Konya: Selçuk Üniversitesi Sağlık Bilimleri Enstitüsü, Doktora Tezi.

Akuthota, V. \& Nadler, S. F. (2004.) Core Strengthening. Arch Phys Med Rehabil, 85 (3). 86-92.

Arı, E., Çakmak, E., Nefesoğlu, İ. C., Karatopak, T., Özden, A., Gürbüz, C., Özsoy, G. (2017). The Evaluation of Young Football and Basketball Players in Terms of Different Agility Tests. The Journal of International Anatolia Sport Science, 2(3), 216-226.

Ari, E., Deliceoglu, G. (2020). The Examination of Some Anthropometric and Motoric Characteristics of Students Aged Eight Years According to Their Maturation Level. Baltic Journal of Health and Physical Activity, 12 (2): 45-63.

Bostanci, Ö., Kabadayi, M., Yilmaz, A. K., Mayda, M. H., Yilmaz, Ç., Erail, S., \& Karaduman, E. (2020). Influence of Eight Week Core Strength Training on Respiratory Muscle Strength in Young Soccer Players. International Journal of Applied Exercise Physiology, 9(6), 221-226.

Boyac1, A. ve Afyon, Y. A. (2017). The Effect the Core training to Physical Performance in Children. Journal of Education and Practice. 8(33): 85

Erol, E. (1992). Çabuk Kuvvet Çalışmalarının 16-18 Yaş Grubu Genç Basketbolcuların Performansı Üzerine Etkisinin Deneysel Olarak İncelenmesi. Ankara: Gazi Üniversitesi Sağlık Bilimleri Enstitüsü, Yüksek Lisans Tezi.

Gambetta, V. (2007). Athletic Development. The Art and Science of Functional Sports Conditioning. Champaign, IL: Human Kinetics., 21. 
Günay, M., Sevim, Y., Savaş, S., \& Erol, A. (1994). Pliometrik Çalışmaların Sporcularda Vücut Yapısı Ve Sıçrama Özelliklerine Etkisi. H.Ü. Spor Bilimleri Fakültesi, (4), 38. Gür, F., \& Ersöz, G. (2017). Kor Antrenmanın 8-14 Yaş Grubu Tenis Sporcularının Kor

Kuvveti, Statik Ve Dinamik Denge Özellikleri Üzerindeki Etkisinin Değerlendirilmesi. Ankara Üni. Spormetre Spor Bilimleri Dergisi, 15(3): 129-138.

Gürpınar, B., Sözeri, B., Tuncel, F., \& Erol, A. (2009). Yaş Grubu Erkek Basketbolcularda

Çabuk Kuvvet Antrenmanlarının Sıçrayarak Şut Yüzdesine Etkisinin İncelenmesi.

Gazi Beden Eğitimi ve Spor Bilimleri Dergisi, 14(3), 3-12.

Kelley, B. (2003). Shooting the J, Basketball Coach. Inti Chiristian H.S Philadelphia.

Larousse, M. (1988). Meydan Yayınevi, (2)-813.

Malone, L., Gervais, P., \& Steadward, R. (2002). Shooting Mechanics Related To Player

Classification And Free Throw Success İn Wheelchair Basketball. Journal of Rehabilitation Research and Development, 39 (6): 701-709.

Mayda, M. H., Karakoc, O., \& Ozdal, M. (2016). The Investigation of Some Physical, Physiological and Anthropometric Parameters of Visually Impaired and NonImpaired a National Male Judoka. Journal of Education and Training Studies, 4(6), 192-198.

Mcgill, S. (2010). Core Training: Evidence Translating to Better Performance And İnjury Prevention. Journal of Strength and Conditioning Research, 32 (3). 33-46.

Özmen, T., Doğan, H., \& Güneş , G. Y. (2017). Prepubertal Amatör Cimnastikçilerde Dinamik Denge, Dikey Sıçrama ve Gövde Stabilitesi Arasındaki İlişki. Spor Bilimleri Dergisi, 28(1), 24-9.

Samson, K. (2005). The Effects of A Five-Week Core Stabilization Training Program On Dynamic Balance İn Tennis Athletes. USA: Master Thesis, West Virginia University.

Sevim, Y. (1991). Basketbol. Ankara: Gazi Büro Kitabevi.

Sharrock, C., Cropper, J., Mostad, J., Johnson, M., \& Malone, T. (2011). A Pilot Study Of Core Stability And Athletic Performance: Is There A Relationship. The International Journal of Sports Physical Therapy, 6,63-67.

Steven, Z. G., John, D. C., Deydre, S. T., Samuel, S. W., Alison, C. W., Jessica, L. D., Michael, E. R. (2011). Brief psychosocial education, not core stabilization, reduced incidence of low back pain: Results from the prevention of low back pain in the military (POLM) cluster randomized trial. BMC Medicine, 20, 119: 128

Şen, C. (1997). Deplasmanlı Milli Ligde Oynayan Basketbolcuların Üst Ekstremite Morfolojik Özellikleri, İstemli Maksimal Hareket Genişlikleri, İzometrik Kuvvet Ve Serbest Atış Arasındaki İlişkileri. Adana: Çukurova Üniversitesi, Sağlik Bilimleri Enstitüsü.

Willardson, J. (2014). Developing The Core. United States. Human Kinetics, 13-114.

Yilmaz, A. K., Kabadayi, M., Mayda, M. H., Bostanci, Ö., Yilmaz, Ç. (2020). Influence of core strength training on peak muscle torque of quadriceps and hamstring in young soccer players. Kinesiologia Slovenica, 26(3), 48-59. 
Creative Commons licensing terms

Authors will retain the copyright of their published articles agreeing that a Creative Commons Attribution 4.0 International License (CC BY 4.0) terms will be applied to their work. Under the terms of this license, no permission is required from the author(s) or publisher for members of the community to copy, distribute, transmit or adapt the article content, providing a proper, prominent and unambiguous attribution to the authors in a manner that makes clear that the materials are being reused under permission of a Creative Commons License. Views, opinions and conclusions expressed in this research article are views, opinions and conclusions of the author(s). Open Access Publishing Group and European Journal of Physical Education and Sport Science shall not be responsible or answerable for any loss, damage or liability caused in relation to/arising out of conflict of interests, copyright violations and inappropriate or inaccurate use of any kind content related or integrated on the research work. All the published works are meeting the Open Access Publishing requirements and can be freely accessed, shared, modified, distributed and used in educational, commercial and non-commercial purposes under a Creative Commons attribution 4.0 International License (CC BY 4.0). 